\title{
Correction to: Clear-cell carcinoma originating from cesarean section scar: two case reports
}

Seyedeh Razieh Hashemi ${ }^{1}$, Mahdi Morshedi ${ }^{2}$, Houshyar Maghsoudi ${ }^{3}$, Arezoo Esmailzadeh ${ }^{1,4^{*}}$ and Ibrahim Alkatout ${ }^{5}$

\section{Correction to: J Med Case Reports (2021) 15:146} https://doi.org/10.1186/s13256-021-02775-9

Following publication of the original article [1], the authors identified an error in the author name of Arezoo Esmailzadeh.

The incorrect author name is: Arezoo Esmaeilzadeh The correct author name is: Arezoo Esmailzadeh

The author group has been updated above and the original article [1] has been corrected.

\section{Author details}

'Department of Obstetrics and Gynecology, Baqiyatallah University of Medical Sciences, Tehran, Iran. ${ }^{2}$ Department of Surgery, Trauma Research Center, Baqiyatallah University of Medical Sciences, Tehran, Iran. ${ }^{3}$ Department of Radiology, Baqiyatallah University of Medical Sciences, Tehran, Iran. ${ }^{4}$ Endometriosis Research Center, Iran University of Medical Sciences (IUMS), Tehran, Iran. ${ }^{5}$ Kiel School of Gynaecological Endoscopy, University Hospital Schleswig-Holstein,

Campus Kiel, Arnold-Heller-Str. 3, Haus 24, 24105 Kiel, Germany.

Published online: 10 August 2021

The original article can be found online at https://doi.org/10.1186/s13256021-02775-9.

*Correspondence: dr.a.esmailzadeh@gmail.com

1 Department of Obstetrics and Gynecology, Baqiyatallah University of Medical Sciences, Tehran, Iran

Full list of author information is available at the end of the article

\section{Reference}

1. Hashemi SR, Morshedi M, Maghsoudi H, Esmailzadeh A, Alkatout I. Clear-cell carcinoma originating from cesarean section scar: two case reports. J Med Case Reports. 2021;15:146. https://doi.org/10.1186/ s13256-021-02775-9.

\section{Publisher's Note}

Springer Nature remains neutral with regard to jurisdictional claims in published maps and institutional affiliations.

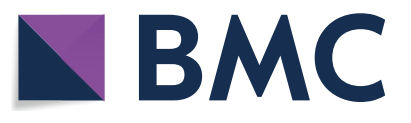

(c) The Author(s) 2021. Open Access This article is licensed under a Creative Commons Attribution 4.0 International License, which permits use, sharing, adaptation, distribution and reproduction in any medium or format, as long as you give appropriate credit to the original author(s) and the source, provide a link to the Creative Commons licence, and indicate if changes were made. The images or other third party material in this article are included in the article's Creative Commons licence, unless indicated otherwise in a credit line to the material. If material is not included in the article's Creative Commons licence and your intended use is not permitted by statutory regulation or exceeds the permitted use, you will need to obtain permission directly from the copyright holder. To view a copy of this licence, visit http://creativecommons.org/licenses/by/4.0/. The Creative Commons Public Domain Dedication waiver (http://creativecommons.org/publicdomain/zero/1.0/) applies to the data made available in this article, unless otherwise stated in a credit line to the data. 